\title{
REJUVENATION OF MELOSIRA GRANULATA (BACILLARIOPHYCEAE) RESTING CELLS FROM THE ANOXIC SEDIMENTS OF DOUGLAS LAKE, MICHIGAN.
}

\section{LIGHT MICROSCOPY AND ${ }^{14} \mathrm{C}$ UPTAKE'}

\author{
L. Sicko-Goad, ${ }^{2}$ E. F. Stoermer
}

Greal Lakes Research Division. The University of Michigan, Ann Arbor, Michigan 48109

and

\section{G. Fahnenstiel}

Great Lakes Environmental Research Laboratory, National Oceanic and Atmospheric Administration, 2900 Washtenaw Ann Arbor, Michigan 48104

\begin{abstract}
Resting cells of Melosira granulata (Ehr.) Ralfs utere collected from the anoxic sediments of Douglas Lake, Michigan. Sediment containing M. granulata u'as inoculated into distilled water and incubated in a growth chamber for one week during which obseriations were made on the cytological differentiation process. Cells classified as "condensed," i.e. containing a dark brown cytoplasmic mass were identified as resting cells. The differentiation process consisted of a series of gradual cytological changes that included elongation of the groplasmic mass and recognition of definable organelles to the point where the cells were non-distinguishable from water column vegetatize cells. Differentiating cells accumulated large polyphosphate and lipid gramules. However, these granules disappeared just prior to cell dizision. The complete differentiation or rejuvenation sequence occurred in some cells in less than $24 \mathrm{~h}$. However, not all dormant cells rejuvenated at the same time and it was observed that the lag period for rejuvenation increased with resting cell age (depth of burial in sediments). In the ${ }^{14} \mathrm{C}$ uplake studies, label was initially observed in condensed slate cells. The label gradually progressed to the more differentiated forms. Total carbon uptake during the rejuvenation process was initially lower in the rejuzenating cells, but roughly equal to water column populations after $8 \mathrm{~h}$, indicating a period of high metabolic activity in the rejuvenating cells between $l$ and $8 h$.
\end{abstract}

Key index words: diatoms; Melosira; rejuvenation; resting cells

Extremely long periods of survival under inimical conditions are well known for a large number of algae and this topic has elicited much comment and considerable research (for reviews see Fogg 1969 , Davis 1972, Schlichting 1974, Fryxell 1983). Although certain cyanobacteria are apparently able to survive desiccation in a vegetative condition, prolonged survival in aquatic habitats is usually associated with the formation of morphological modifications such as spores, cysts, or akinetes. Most species

\footnotetext{
'Accepted: 27 September 1985.

Address for correspondence and reprints.
}

of eukaryotic algae capable of prolonged survival in aquatic habitats have specialized modifications of vegetative cells or specifically modified and resistant life-cycle stages.

Studies of prolonged darkness survival (Antia and Cheng 1970, Bunt and Lee 1972, Smayda and Mitchell-Innes 1974, Palmisano and Sullivan 1982) and desiccation (Bristol J920, Evans 1958 and 1959, McLean 1967, Parker et al. 1969) are abundant. The most common mechanisms for survival under adverse conditions seem to be (1) formation of resting spores (Hendey 1964, Hargraves 1976); (2) formation of cysts (Wall et al. 1970, Sandgren 1983). and (3) formation of "resting cells" where there is no distinct external modification, but there is some, probably physiological, modification of the vegetative cell (Anderson 1975, Kalley et al. 1977, Bisalputra and Antia 1980, McLean 1969).

The classic study of Nipkow (1950) and later works by Lund (1954) and Stockner and Lund (1970) demonstrated that certain populations of the diatom genus Melosira are capable of surviving sinking and burial in sediments for periods of at least years and perhaps decades. These cells are able to survive sediment burial considerably longer than planktonic species of other major divisions that do have specialized survival cells. Furthermore, cells that survive burial can return to a state that is visually indistinguishable from "normal" vegetative cells within hours of being returned to suitable growth conditions. Rejuvenation of populations of "physiologically" resting cells of Melosira granulata (Ehr.) Ralfs obtained from the anoxic sediments of Douglas Lake, Michigan, and the sequence of cytological events that occur in this process are the subject of the following report.

\section{MATERIALS AND METHODS}

A core of Douglas Lake from South Fishtail Bay was obtained using a benthos corer at approximately 0530 on July 19, 1989. The core was kept in subdued light and sectioned at $1 \mathrm{~cm}$ intervals, Three milliliters of each core segment (including interstitial water) from depths of $1,10,20$, and $90 \mathrm{~cm}$ was added to approximately $2 \mathrm{~L}$ of deionized water in non-toxic sterile rotary shaker bottles. Deionized water was used to provide the least nutrient-rich conditions possible. Similar rejuvenation responses 
occurred when resting cells from sediments were resuspended in filtered lake water. The bottles were put into a growth chamber on a rotary shaker platform with the growth chamber set at $18^{\circ}$ C, a 16:8 h L.D cycle, and a cool white light level of $50 \mu \mathrm{E} \cdot \mathrm{m}^{-2}$. $s^{-1}$. Samples were withdrawn at $15 \mathrm{~min}$ intervals for the first hour, hourly intervals for the first $8 \mathrm{~h}, 2 \mathrm{~h}$ intervals for hours 816 , and subsequently every $8 \mathrm{~h}$ for 6 days. The light cycle of the growth chamber was initialized with placement of the shaker boules into the chamber. The time interval between core collection and placement of samples into the growth chamber was ca. $30 \mathrm{~min}$.

As samples were withdrawn, fixative was added to the sample tubes to give a final concentration of $1 \%$ paraformaldehyde, $1 \%$ glutaraldehyde, and $0.05 \mathrm{M}$ cacodylate buffer at $\mathrm{pH} 7.2$ (Lazinsky and Sicko-Goad 1979). Light microscope observations were made on both living and preserved samples with a Leitz Dialux 20 microscope with an optical system furnishing a numerical aperture of 1.32. For electron microscopy, samples were post-fixed in $1 \%$ osmium tetroxide in pH 7.2, 0.05 M cacodylate buffer for I h, dehydrated in a graded ethanol propylene oxide series, and embedded in Epon. Permanent epoxy mounts were also made from the $\mathrm{OsO}_{5}$, post-fixed sample.

Water column samples from Douglas Lake containing populations of Melosirn were also collected to compare the primary productivity of lakewater populations at the time sediment experiments were conducted with those populations rejuvenated from the sediments. Water column samples were collected from the epilimnion and transported back to the lab in the cold and dark. Average irradiance of water column samples at the time of collection was ca. $300 \mu \mathrm{E} \cdot \mathrm{m}^{-2} \cdot \mathrm{s}^{-1}$. Primary production was measured with the ${ }^{10} \mathrm{C}$ technique (Vollenweider 1974). Lakewater and sediment samples (1-3 mL of sediment and approximately $11 / 2 \mathrm{~L}$ DDW) were incubated in $2-\mathrm{L}$ bottles at $100 \mu \mathrm{E} \cdot \mathrm{m}^{-2} \cdot \mathrm{s}^{-1}$ for $1-104 \mathrm{~h}$ with $2-10 \mu \mathrm{Ci}$ of $\mathrm{NaH}{ }^{1} \mathrm{CO}_{3}-$. Upon completion of the incubation, the samples were preserved with either glutaraldehyde, paraformaldehyde and sodium cacodylate (Lazinsky and Sicko-Goad 1979), or 1\% formalin. Immediately. these samples were filtered onto $0.45 \mu \mathrm{m}$ membrane filters, placed on slides that have been vigorously washed in strong detergent, rinsed, and dipped in a solution containing $5 \mathrm{~g} \times \mathrm{gelatin}$ and $0.5 \mathrm{~g}$ chrome alum per liter (Knoechel and Kalff 1976), and then fumed with boiling acetone (Paerl and Stull 1979). Slides were dipped in NTB 3 pholographic emulsion, exposed for 4-30 h, and developed for track autoradiography as described in Knoechel and Kalf (1976). The amount of carbon fixed per cell was calculated using $\mathrm{pH}$ and alkalinity measurements (Vollenweider 1974). Light and epifluorescent microscopy were used to count tracks and determine which cells contained autofluorescent chloroplasts.

\section{RESULTS}

For discussion purposes throughout the text, we have described the four following cell types which are easily distinguished by light microscopy: (a) Nonviable. This category of cells is a mixture of two cell types including both empty frustules and cells containing small green globules or cytoplasmic fragments that may be weakly autofluorescent; (b) Condensed. Cells in this category have the protoplasm reduced to brownish globules with no visible substructure. The protoplasm is autofluorescent and is most frequently found in the sulcus region although it may be found occasionally adjacent to the valves. These cells are easily distinguished from cells with non-viable cytoplasmic fragments by their intense coloration (Fig. I); (c) Partially expanded. Cells in this category are somewhat opaque with the cytoplasmic mass elongated and usually located near the sulcus: (d) Fully expanded. Cells are indistinguishable from normal vegetative cells. This category of cells, for counting purposes, also includes cells that are packed with storage products or are in the process of dividing.

The populations of cells classified as "condensed" appear to be the vegetative resting form of Melosira. This statement is based on light microscope observations and ${ }^{14} \mathrm{C}$ uptake determined by track autoradiography on which we elaborate below. An ordered sequence of rejuvenation stages was observed to occur within $24 \mathrm{~h}$ following resuspension of the sediment containing the resting cells. The initial step in the rejuvenation sequence is the expansion of cytoplasm in condensed cells from the intensely colored brownish compact globule located near the sulcus (Fig. 1). During this initial expansion stage, the cytoplasmic mass begins to lose its intense coloration and the chloroplasts become identifiable as discrete ovoid organelles still located near the sulcus (Fig. 2). The early expansion state is also characterized by the proliferation of lipids and polyphosphate. Small storage granules first appear scattered throughout the cell (Fig. 3). As cytoplasmic expansion progresses, the cells are characterized by what appear to be coalesced lipid granules (Fig. 4). At this stage, the cytoplasmic expansion and differentiation are incomplete but the chloroplasts assume a more parietal position. Further cytoplasmic expansion is then characterized by the appearance of large polyphosphate granules which often appear mottled (Fig. 5). The polyphosphate bodies were confirmed by leadsulfide staining (Ebel et al. 1958). At this stage both polyphosphates and lipid may be present in the cell. Completely differentiated cells (i.e. those non-distinguishable from vegetative cells growing in the lake) may contain storage products (Fig. 6). However, just prior to (Fig. 7) and during cell division (Fig. 8), no storage products are present and when the cells are established as vegetative cultures (e.g. after a period of one week), lipid and polyphosphate granules are rare.

Cell counts of initial sediment samples (Table l) demonstrate that the numbers of cells in the condensed state diminish with depth from approximately $32 \%$ in the surficial sediments to $7 \%$ at the $20 \mathrm{~cm}$ depth. Extrapolation of data from recent pollen profiles of Douglas Lake (Webb 1973, Andresen 1976) would suggest that the linear sedimentation rate is approximately 0.6 to $0.7 \mathrm{~cm} /$ year, making the 10 and $20 \mathrm{~cm}$ samples roughly 15 and 30 years old. It is also evident from Table 1 that the lag period for rejuvenation also increases with depth.

Cumulative carbon uptake data (Table 3 and Fig. 9) show that the population of $8 \mathrm{~h}$ cells has most of the carbon associated with the condensed and partially expanded states. With time, there is a net movement of label into cells that are fully expanded (including cells packed with storage products as well 


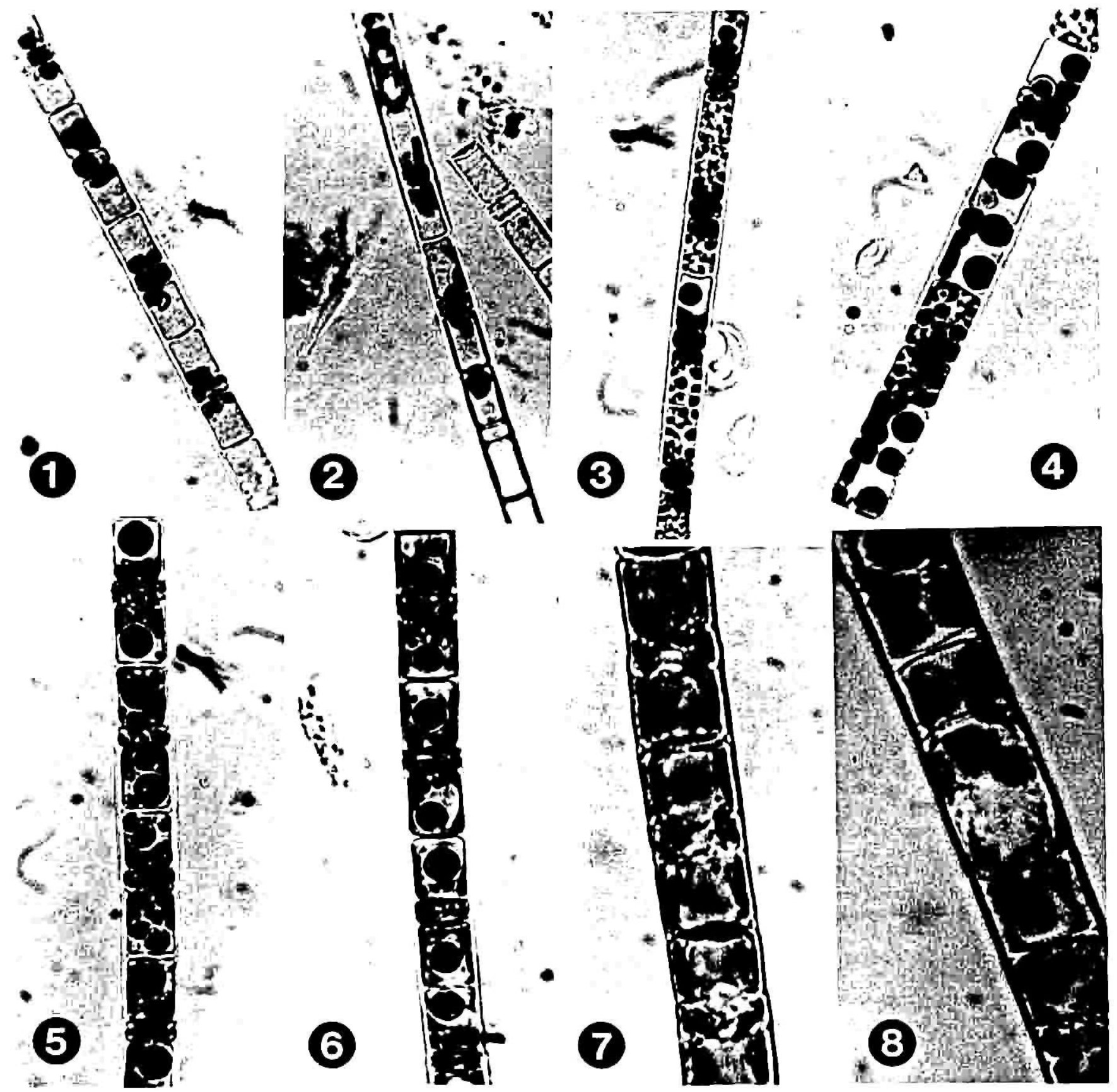

Fics. 1-8. Phestemicrographs of stages of rejuvenation of Melosirn granulata resting cells. Fic. I. Condensed state cell. Note intense coloration of cresplismic mass in the sulcus region. Fic. 2. Farly expansion stage. Chloroplasts are beginning to elengate althemgh they are still located near the sulcus. Fic: 3 Farly expansesn stige accompaned by the accumulaten of storage gramules. These small storage

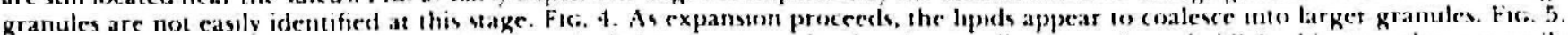
Polsphosphate granules become recognizalile at the light microscope levet and generally appear "motted." At this stage they are easily differentiated from lipirs. Fic: 6. Fulls expanded cells are chatacieried by the arrangement of evesplasm at the cell periphery and al the contral cytoplasmic bridge. Storage preslucts may still be present, although they are larger and fewer in number. Fics. 7, 8 . Cells

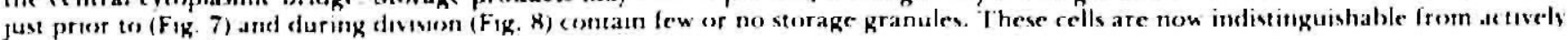
growing water column populatioms.

as dividing cells). The initial hourly uptake rates (Table 2) of actively growing water column populations of .M. granulatn are much higher than sediment samples initially placed into the light. However, after $8 \mathrm{~h}$, water column and sediment cumulative rates are roughly equal (Table 3 ), indi- cating a period of high metabolic activity in the sediment samples between 1 and 8 h. Hourly uptake rates after 56 and $104 \mathrm{~h}$ of growth are essentially the same. The total cumulative carbon uptake data (Table 3) show that there is a cominuous increase in carbon content with time up to $104 \mathrm{~h}$, and that 
TABLE 1. Percent composition of Melosira rejuzenation experiments from resuspended sediments as a function of sediment depth and time. Results are presented as the mean ( $\pm I S E$ ). Refer to lext for cytological description of calegories.

\begin{tabular}{|c|c|c|c|c|}
\hline & Non-viable & Condensed & Partly expanded & Full expanded \\
\hline \multicolumn{5}{|l|}{ Surficial } \\
\hline $\begin{array}{r}t=\quad 0 \\
8 \\
32 \\
56 \\
80 \\
104 \\
152\end{array}$ & $\begin{array}{l}46.99( \pm 4.33) \\
36.89( \pm 3.81) \\
46.20( \pm 1.84) \\
45.79( \pm 5.16) \\
26.96( \pm 5.74) \\
38.88( \pm 9.47) \\
30.03( \pm 5.26)\end{array}$ & 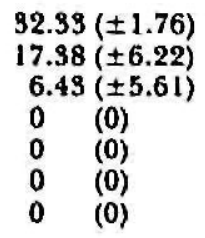 & $\begin{array}{c}16.33( \pm 1.86) \\
6.15( \pm 1.96) \\
0.58( \pm 0.91) \\
0.56( \pm 0.59) \\
0.26( \pm 0.27) \\
0.26( \pm 0.29) \\
3.12( \pm 1.99)\end{array}$ & $\begin{array}{c}5.0( \pm 1.53) \\
99.57( \pm 5.21) \\
46.78( \pm 5.49) \\
59.65( \pm 5.10) \\
73.99( \pm 5.79) \\
60.84( \pm 9.31) \\
66.86( \pm 3.28)\end{array}$ \\
\hline \multicolumn{5}{|l|}{$10 \mathrm{~cm}$} \\
\hline $\begin{array}{r}1-\quad 0 \\
8 \\
32 \\
56 \\
80 \\
104 \\
152\end{array}$ & $\begin{array}{l}67.33( \pm 8.68) \\
64.16( \pm 7.59) \\
87.79( \pm 7.12) \\
76.43( \pm 7.61) \\
71.04( \pm 4.65) \\
67.43( \pm 7.08) \\
66.47( \pm 3.23)\end{array}$ & $\begin{array}{l}23.39( \pm 4.9) \\
20.80( \pm 9.95) \\
0.29( \pm .28) \\
2.11( \pm 1.65) \\
0 \quad(0) \\
1.49( \pm .14) \\
0 \quad(0)\end{array}$ & $\begin{array}{l}9.0( \pm 3.5) \\
2.02( \pm 1.37) \\
2.08( \pm 1.96) \\
2.11( \pm 1.13) \\
0 \quad(0) \\
0.29( \pm .38) \\
0 \quad(0)\end{array}$ & $\begin{array}{c}0.9( \pm 0.3) \\
13.00( \pm 5.59) \\
9.82( \pm 7.92) \\
19.34( \pm 7.06) \\
28.96( \pm 4.65) \\
30.86( \pm 7.25) \\
99.59( \pm 2.70)\end{array}$ \\
\hline \multicolumn{5}{|l|}{$20 \mathrm{~cm}$} \\
\hline $\begin{array}{r}1=\quad 0 \\
8 \\
32 \\
56 \\
80 \\
104 \\
152\end{array}$ & $\begin{array}{c}91.67( \pm \$ 1.18) \\
87.08( \pm 2.22) \\
95.87( \pm 0.60) \\
97.29( \pm 1.66) \\
100 \quad( \pm 0) \\
84.94( \pm 9.88) \\
96.49( \pm 1.61)\end{array}$ & $\begin{array}{c}6.67( \pm 2.6) \\
12.92( \pm 2.22) \\
4.12( \pm 0.60) \\
2.71( \pm 1.66) \\
0 \quad(0) \\
0 \quad(0) \\
0.64( \pm 0.63)\end{array}$ & $\begin{array}{ll}1.67 & ( \pm 1.2) \\
0 & (0) \\
0 & (0) \\
0 & (0) \\
0 & (0) \\
0.30( \pm 0.28) \\
0.64( \pm 0.64)\end{array}$ & $\begin{array}{ll}0 & (0) \\
0 & (0) \\
0 & (0) \\
0 & (0) \\
0 & (0) \\
15.36( \pm 9.62) \\
2.29( \pm 2.25)\end{array}$ \\
\hline
\end{tabular}

Melosira populations collected from the water column have similar carbon content. ${ }^{14} \mathrm{C}$ label is initially located in condensed and partially expanded cell types. However, as incubation time increases, the label is associated with the more advanced rejuvenation stages (Fig. 9).

\section{DISCUSSION}

Development of a mechanism allowing prolonged survival of diatoms could be of considerable selective advantage to populations growing in both temperate lakes and oceans. Although spores have generally been regarded as benthic resting stages of planktonic species (Gran 1912), evidence from natural populations would suggest that spores (as morphologically distinct entities) may not represent the sole source of "seed material" for the sudden onset of phytoplankton blooms. For example, spores are more commonly found in neritic species than in oceanic or freshwater species (Hargraves and French 1983). Hargraves and French (1975, 1983) demonstrated

TABLE 2. Hourly bicarbonate uptake rates for $1 \mathrm{~h}$ " $\mathrm{C} C \mathrm{C}$ experiments as a function of grouith time. Total includes all cell calegories.

\begin{tabular}{cc}
\hline Growth condition & $\begin{array}{c}\text { Total houtly ratr } \\
\left(\mathrm{pg} C \cdot \text { cell }^{-} \cdot \mathrm{h}^{-1}\right)\end{array}$ \\
\hline $1 \mathrm{~h}$ & $0.183 \pm 0.025$ \\
$56 \mathrm{~h}$ & $0.95 \pm 0.04$ \\
$104 \mathrm{~h}$ & $0.579 \pm 0.065$ \\
$1 \mathrm{~h}$ dark uptake & $0.00028 \pm 0.00028$ \\
I h initial water column & \\
(Melosira population) & $0.61 \pm 0.05$ \\
\hline
\end{tabular}

that diatom resting spores (hypnospores) persist in culture for only as long as two years and in the sediments for only a few weeks, although Garrison (1981) demonstrated the persistence of spores in Monterey Bay. Moreover, some important coastal phytoplankton species such as Skeletonema costatum and Asterionella glacialis do not form morphologically distince resting cells. The survival of populations that form physiologically dormant cells may be more prolonged and efficient than species that form hypnospores. This may explain the persistence of viable cells at great depths in the ocean (Malone et al. 1973, Anderson 1975, 1976. Platt et al. 1983). The resting cell strategy also avoids metabolic and material loss, which occurs as a consequence of spore formation in diatoms. The problem associated with assuming that spores are a benthic resting stage is more pronounced in freshwater systems because resting spores are uncommon. Lund $(1954,1955$, 1959) has presented evidence which suggests that

TA81.F 3. Cumulative bicarbonale uplake as a function of longelerm continuous exposure and growth. Total includes all cell catrgories.

\begin{tabular}{|c|c|}
\hline Time in culture & $\begin{array}{l}\text { Cumulative uphate } \\
\left.\text { (PR C celf }-1 \cdot h_{-1}^{-1}\right)\end{array}$ \\
\hline $\begin{array}{r}8 \mathrm{~h} \\
16 \mathrm{~h} \\
32 \mathrm{~h} \\
56 \mathrm{~h} \\
104 \mathrm{~h}\end{array}$ & $\begin{aligned} 7.92 & \pm 0.60 \\
10.07 & \pm 0.66 \\
15.95 & \pm 0.59 \\
24.05 & \pm 0.82 \\
27.4 & \pm 0.85\end{aligned}$ \\
\hline $\begin{array}{l}8 \mathrm{~h} \text { water column } \\
\text { (Melasira population) }\end{array}$ & $6.70 \pm 0.95$ \\
\hline
\end{tabular}




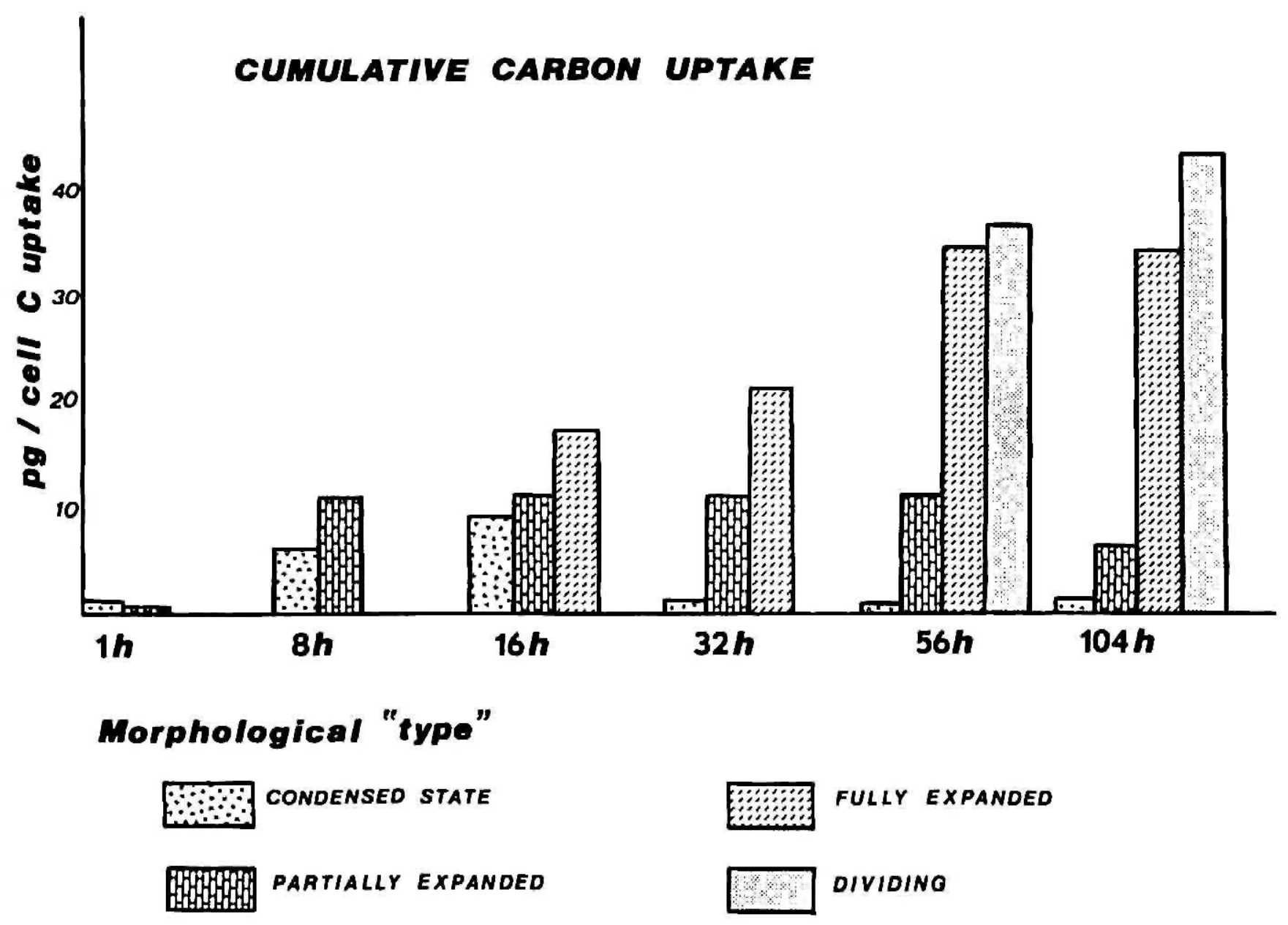

Fic, 9. Distribution of ${ }^{14} \mathrm{C}$ uptake in rejuvenated $M$. granulata cells as a function of time.

the perennation of Melosira italica subsp. subarctica in English lakes involves a regular cycle of growth during circulation, sinking into sediments, and entrainment into the plankton during the next circulation event. Lund (1949, 1950a, b, Lund et al. 1963) puzzled over massive blooms of Asterionella formosa followed by apparently complete disappearance from the water column and subsequent rapid assumption of dominance with return of favorable conditions. He also observed apparently living vegetative cells in surficial sediments.

Our data suggest that Melosira is indeed capable of surviving prolonged periods (up to perhaps two decades) in a dormant state that is externally nondistinguishable from a vegetative cell. The cells, which we have identified by both light microscopy and autoradiography to be the physiologically "resting" cells are, however, distinguished from vegetative cells by their distinctive cytology which consists of a condensed, dark brown cytoplasmic mass. Review of the literature on cytological descriptions of dormant cells (including spores) reveals that this description is also true for other species (Anderson 1975. Hargraves and French 1975, Hargraves 1979.
Hoban et al. 1979), and both compaction and conservation of key organelles may be the key to prolonged survival in both resting spores and resting cells.

The resting cells of $M$. gramulata in this study were taken from core depths that may correspond to 20 years of burial in anoxic lake sediments. This is significant from both the standpoint of time and dormancy conditions. These cells are considerably older than those previously shown to rejuvenate or germinate (e.g. Hargraves and French 1983). Furthermore, viable resting cells were obtained from anoxic lake sediments, while anoxia is considered an environmental factor that reduces spore viability (Davis et al. 1980. Hollibaugh et al. 1981). Out data on cumulative carbon uptake and hourly uptake rates during the rejuvenation sequence are remarkably consistent with physiological data presented for germinating spores of several diatoms (Hollibaugh et al. 1981). However, the semantics involved in comparing a true germination from a spore with rejuvenation of dormant cells makes the staging difficult to compare. In both Melosira and other diatoms (e.g. Anderson 1976. Hollibaugh et al. 1981). placement 
of dormant cells under conditions that favor resumption of active growth results in an immediate. dramatic increase in carbon fixation. In Melosira, the ${ }^{14} \mathrm{C}$ uptake is initially associated with cells in the condensed state. As incubation time increases, the label is found in more advanced rejuvenation stages. Melosira is also somewhat unusual in that we found large increases in storage products during cytoplasmic expansion state and prior to cell division. Increases in storage products are usually associated with the formation of resting cells and spores (McLean 1967, 1969, Anderson 1975, von Stosch and Fecher 1979, Bisalputra and Antia 1980). However, we feel that it is not unreasonable to speculate that the rejuvenation (germination)-dormancy sequence is a continuum and reversible.

The increased lag period of rejuvenation with depth (i.e. age of dormant cells) is not unusual. Hollibaugh et al. (1981) reported similar results with three Chaetoceros species and it has been suggested (Anderson 1976) that staggered growth resumption as we observed, may be yet another survival mechanism, ensuring that a portion of viable cells are retained, should unfavorable growth conditions occur after resumption of growth.

Simonsen (1979) has postulated that resting spore formation is a primitive characteristic that has been retained by some species. In view of our findings and those of other investigators, we find this statement quite plausible considering the cytological and physiological characteristics that are common to rejuvenating resting cells and germinating spores. Populations that have no distinctive resting stage based on external morphology have probably gone unnoticed in natural assemblages, and further work both in marine and freshwater ecosystems needs to be done to determine the abundance and role of species with resting cells.

We would like to acknowledge the able technical assistance of $\mathrm{D}$. Lazinsky. Supported by NSF Grant OCE 89-09142. Contribution No. 491 of the Great Lakes Research Division. Contribution No. 470 of the Great Lakes Environmental Research Lab.

Anderson, O. R. 1975. The ultrastructure and cytochemistry of resting cell formation in Amphora coffacformis (Bacillariophyceac). J. Phycol. 11:272-81.

1976. Respiration and photosynthesis during resting cell formation in Amphora coffaeformis (Ag.) Kütz. Limnol. Oceanogr. $21: 452-6$.

Andresen, N, A. 1976. Recent diatoms from Douglas Lake, Cheboygan County. Michigan. Doctoral dissertation. Depart. ment of Botany. University of Michigan, $419 \mathrm{pp}$.

Antia, N.J. \& Cheng, J. Y. 1970. The survival of axenic cultures of marine plank tonic algae from prolonged exposure to darkness at 20. C. Phyrologia 9:179-84.

Bisalputra, T. \& Antia, N.J. 1980. Cytological mechanism underlying darkness survival of the unicellular red alga Porphyridium cruentum. Bot. Mar. 23:719-30.

Bristol, B. M. 1920. On the alga flora of some desiccated English soils: an important factor in soil biology. Ann. Bot. 34:35-80.

Bunt, J. S. \& Lee, C. C. 1972 . Data on the composition and dark survival of four sea-jce microalgae. Limnol. Oceanogr, 17:45861.
Davis, C. O., Hollibaugh, J. T., Seibert, D. L. R.. Thomas, W. H. \& Harrison, P. J. 1980. Formation of resting spores by Leptocylindrus danicus (Bacillariophyceac) in a controlled ecosystem experiment. J. Phycal. 16:296-902.

Davis, J. S. 1972. Survival records in the algae, and the survival role of certain algal pigments, fat, and mucilaginous substances. The Biologist 54:52-93.

Ebel.J. P., Colas, J. \& Muller, S. 1958. Recherches cytochimiques sur les polyphosphates inorganiques contenus dans les organismes vivants. II. Mise au point de methods de detection cytochimiques specifiques des polyphosphates. Exp. Cell. Res. 15:28-36.

Evans. J. H. 1958. The survival of freshwater algae during dry periods. 1. An investigation on the algae of five small ponds. J. Ecol. 46:149-76.

1959. The survival of freshwater algae during dry periods. 11. Drying experiments. J. Ecol. 47:55-71.

Fogg, G. E. 1969. Survival of algae under adverse conditions. Symposium of the Society of Experimental Biologists. Vol. 23. Dormanç and Surival. Academic Press, New York, pp. $123-42$.

Fryxell, G. A. (Ed.) 1983. Sunival Strategies of the Algae. Cambridge University Press, New York, 144 pp.

Garrison, D. L. 1981. Monterey Bay phytoplankton. It. Resting spore cycles in coastal diatom populations. J. Plank. Res. 3: 137-56.

Gran, H. H. 1912. Pelagic plant life, In Murray J., Hort J. [Eds.] The Depths of the Orean. MacMillan. London, pp. 307-86.

Hargraves, P. E. 1976. Studies on marine plankton diatoms. II. Resting spore morphology. J. Phyrol. 12:118-28.

1979. Studies on marine plankton diatoms. IV. Morphology of Chaeloceros resting spores. Beih. Nova Heduigia 64: 99-120.

Hargraves. P. E. \& French, F. W. 1975. Observations on the survival of diatom resting spores. Brih. Nana Hedurigia 53: 229-38.

1983. Diatom resting spores: significance and stratcgies. In Fryxell, G. A. [Ed.] Survival Siralegies of the Algae. Cambridge University Press. New York, Pp. 49-68.

Hendey. N. I. 1964. An Introductory Account of the Smaller Algae of British Coastal Waters. Part $\dot{V}$. Bacillariophyceae (Diatoms). Fishery Investigations Series IV of U.K. Ministry of Agriculture, Fisheries and Food. Her Majesty's Stationery Office. London, $317 \mathrm{pp}$.

Hoban, M. A., Buck, K. R. \& Fryxell, G. A. 1979. Survival strategies in Antarctic diatoms-interspecific variation in resting cell formation. $J$. Phycol. 15(suppl):27.

Hollibaugh, J. T., Seiber, D. L. R. \& Thomas. W. H. 1981. Observations on the survival and germination of resting spores of three Chartoceros (Bacillariophyceae) species. J. Phycol, 17: $1-9$.

Kalley, J. P., Bisalputra, T. \& Antia, N. J. 1977. Cytological response underlying darkness-survival of the coccoid bluegreen alga Agmenellum quadruplicatum. Bot. Mar. 20:253-62.

Knoechel, R. \& Kalff.J. 1976. Track autoradiography: A method for the determination of phytoplankton species productivity. Limnol. Oceanogr. 21:590-6.

Lazinsky, D. \& Sicko-Goad. L. 1979. Paraformaldehyde-glutaraldehyde as a routine phytoplankton fixative. Micron 10:4950.

Lund, J. W. G. 1949. The dynamics of diatom outbursts, with special reference to Asterionella. Verh. Int. Verrin. Theor. Agneu. Limnol. 10:275-6.

1950a. Studies on Astenonella formosa Hass. II. Nutrient depletion and the spring maximum. Part 1. Observations on Windermere, Esthewaite Water, and Blelham Tarn. J. Ecol. 98:1-14.

- 1950b. Studies on Asterionella formosa Hass. 11. Nutrient depletion and the spring maximum. Pant II. Discussion. J. Ecol. 38:15-35.

1954. The seasonal cycle of the plankton diatom. Melosira italica (E.hr.) Kütz. subsp. subartica O. Mull. J. Ecol. 42:15179. 
1955. Further observations on the seasonal cycle of Melosira italica (Ehr.) Kūtz. subsp. subartica O. Mull. J. Ecol. 49: 91-102.

1959. Buoyancy in relation to the ecology of freshwater phytoplankton. Br. Phyeot. Bull. 7, 17 pp.

Lund, J. W. G., Mackereth, F. J. H. \& Mortimer, C. H. 1963. Changes in depth and time of certain chemical and physical conditions and of the standing crop of Asterionella formosa Hass. in the North Basin of Windermere in 1947. Phil. Trans. R. Soc. 246B:255-90.

Malone, T. C., Garside, C. R. \& Roels, O. A. 1973. The possible occurrence of photosynthetic microorganisms in deep-sea sediments of the North Atlantic. J. Phycol. 9:482-8.

McLean, R.J. 1967. Desiccation and heat resistance of the green algae Spongiochloris ispica. Can. J. Bot. 45:1939-8.

1969. Rejuvenation of senescent celis of Spongiochloris typica. J. Phycol. 5:32-7.

Nipkow, F. 1950. Ruheformen planktischer Kieselalgen im geschicheten Schlamm des Zurichsees. Schuriz. Z. Hydrol. 12: 263-70.

Paerl, H. W. \& Stull, E. A. 1979. In defense of grain density autoradiography. Limnol. Oceanogr. 24:1 166-9.

Palmisano. A. C. \& Sullivan, C. W. 1982. Physiology of sea ice diatoms. I. Response of three polar diatoms to a simulated summer-winter transition. J. Phycol. 18:489-98.

Parker, B. C., Schanen. N. S. \& Renner, R. 1969. Viable soil algae from the herbarium of the Missouri Botanical Garden. Ann. Missouri Bot. Gard. 56:113-19.

Platt. T., Subba Rao, D. V., Smith, J. C., Li, W. K., Irwin, B., Horne, E. P. W. \& Sameoto, D. D. 1983. Photosynthetically- competent phytoplankton from the aphotic zone of the deep ocean. Mar. Ecol. Prog. Ser. 10:105-10.

Sandgren, C. D. 1989. Survival strategies of chrysophycean flagellates: reproduction and formation of resistant resting cysts. In Fryxell, G. A. [Ed.] Survival strategies of the algae. Cambridge University Press, New York, pp. 23-48.

Schlichting, H. E., Jr. 1974. Survival of some fresh-water algae under extreme environmental conditions. Trans. Amer. Micros. Soc. 93:610-3.

Simonsen, R. 1979. The diatom system: ideas on phylogeny. Bacillaria 2:9-71.

Smayda, T. J. \& Mitchell-Innes, B. 1974. Dark survival of autotrophic, planktonic marine diatoms. Mar. Biol. (Berl.) 25: 195-202.

Stockner, J. G. \& Lund, J. W. C. 1970. Live algae in post-glacial lake deposits. Limnol. Oceanogr. 15:41-58.

Vollenweider, R. A. (Ed.). 1974, A Manual on Methods for Measuring Primary Production in Aqualic Environments. 2nd Ed. IBP Handbook No. 12. Blackwell Scientific Publs, 225 pp.

von Stosch, H.-A. \& Fecher, K. 1979. "Internal thecae" of Eunotia solrirolii (Bacillariophyceae): Development, structure and function as resting spores. J. Phyrol. 15:239-43.

Wall, D., Guillard, R. R. L., Dale, B., Swift, E. \& Watabe, N. 1970. Calcite resting cysts in Peridinium trothoideun (Stein) Lemmermann, an autotrophic marine dinoflagellate. Phyco. login 9:151-6.

Webb, T., III. 1973. A comparison of modern and presettiemem pollen from southern Michigan (U.S.A.). Ret. Paleobot. Palyn. 16:137-56.

\title{
REJUVENATION OF MELOSIRA GRANULATA (BACILLARIOPHYCEAE) RESTING CELLS FROM THE ANOXIC SEDIMENTS OF DOUGLAS LAKE, MICHIGAN. II. ELECTRON MICROSCOPY'
}

\author{
Linda Sicko-Goad ${ }^{2}$
}

Great Lakes Research Division. The University of Michigan, Institute of Science and Technology, Ann Arbor, Michigan 48109

\section{ABSTRACT}

Detailed cytological changes that accompany the rejuzenation of resting cells of Melosira granulata were studied with the electron microscope. Dormant and viable cells that we previously classified as the condensed state generally contain definable chloroplasts, mitochondria, a nucleus and other cyloplasmic remnants. Howecter, there appears to be a continuous cytoplasmic degradation spectrum and some cells which appear intensely colored with the light microscope have discontinuous chloroplast membranes and few other cytoplasmic remnants. Rejuvenation of viable dormant cells is initially accompanied by the accumulation of both lipids and polyphosphates. In the earliest stages of expansion. these storage products are dispersed throughout the cell. In later stages of expansion, the lipids appear to be coalesced into larger droplets which are easily identified at the light microscope lecel. The fully

\footnotetext{
1 Accepted: 27 September 1985.

- Address for correspondence and reprints.
}

expanded stage is characterized by the normal complement of organelles and their arrangement at the periphery of the cells and central cyloplasmic bridge. These cells appear both anabolically and calabolically active as evidenced by the abundance of endoplasmic reticulum, ribosomes and secretory and lytic vesicles. Prior to cell division, both lipids and polyphosphates are reduced or absent in the cells. The ultrastructural features of the dormant, condensed state in resting cells of $M$. granulata are similar to those described for hypnospores. A rejuvenation sequence that produces cytological features common to resting slate formation could provide a population of cells which could easily revert should environmental conditions become adverse.

Key index words: diatom ultrastructure; Melosira; rejuvenation; resting cells

Although knowledge of the function and fate of resting spores of diatom populations has increased, little attention has been given to cells which function as a vegetative resting state. These resting cells differ 
This document is a scanned copy of a printed document. No warranty is given about the accuracy of the copy. Users should refer to the original published version of the material. 